\title{
Carcinomas with Apocrine Differentiation: Comparison of Clinicopathologic Features with Invasive Breast Carcinoma of No Special Type (NST) in Turkish Patients
}

\author{
Halil KIYICI ${ }^{1}$, Gulnur GULER ${ }^{2}$, Kadri ALTUNDAG ${ }^{3}$ \\ ${ }^{1}$ Mevlana University Faculty of Medicine, Department of Pathology, Konya \\ ${ }^{2}$ Hacettepe University Faculty of Medicine, Department of Pathology, Ankara \\ ${ }^{3}$ Hacettepe University Faculty of Medicine, Department of Medical Oncology, Ankara, TURKEY
}

\begin{abstract}
When a total of 2488 Turkish patients were taken into consideration, carcinomas with apocrine differentiation accounted for $0.7 \%$ of invasive breast carcinomas. The aim of this study was to evaluate clinicopathologic features of this rare type breast carcinoma in Turkish population. To our knowledge, our study has a unique specialty as having broadest group of Turkish patients with apocrine carcinoma, so far. Parameters such as patient's age, tumor size, nodal metastasis, lymphatic - vascular invasion, immunohistochemical expressions of estrogen receptor, progesterone receptor, HER2 status were documented and compared with invasive ductal carcinoma of no special type. Against 20 cases of apocrine carcinoma, a grade-matched control group of 40 invasive ductal carcinoma was formed. Prognostic features such as overall survival period and relapse - free survival period were also studied; but only for a limited follow - up period with an average of approximately 30 months. Usual negativity of estrogen and progesterone receptors in apocrine carcinoma was once more confirmed by this study. Results were consistent with related literature, indicating presence of poor significant difference between clinicopathologic features of apocrine carcinoma and the other invasive ductal carcinomas of breast.
\end{abstract}

Keywords: Apocrine carcinoma, Clinicopathologic features, Estrogen, Progesterone, HER2

\section{ÖZET}

\section{Apokrin Farklılaşma Gösteren Karsinomlar: Türk Hastalarda Özel Olmayan Tip İnvaziv Meme Karsinomu ile Klinikopatolojik} Özelliklerinin Karşılaştırılması

İnvaziv meme karsinomu bulunan toplam 2488 Türk hastanın taranması sonucunda, bunların \%0.7'sinde apokrin farklllaşma gösteren karsinom olduğu saptanmıştır. Bu çalışmanın amacı, nadir görülen bu meme karsinomu tipinin klinikopatolojik özelliklerini, Türk popülasyonunda değerlendirmektir. Bildiğimiz kadarıyla, çalışmamız şimdiye kadar apokrin karsinomlu Türk hastalardan oluşan en geniş gruba sahiptir. Hasta yaşı, tümör çapı, lenf nodu metastazı, lenfatik - vasküler invazyon, immünohistokimyasal östrojen reseptörü, progesteron reseptörü, HER2 tablosu gibi parametrelere bakılıp özel olmayan tip invaziv meme karsinomu ile karşılaşıııımıştır. 20 apokrin karsinomun karşısındaki kontrol grubu, eş farklllaşma dereceli 40 invaziv duktal karsinomdan oluşturulmuştur. Toplam yaşam süresi ve nükssüz yaşam süresi gibi prognostik göstergeler de çalışılmış; ancak ortalama 30 aylık hasta takip süresi nedeniyle sınırlı kalımıştır. Apokrin karsinomun bilinen östrojen ve progesteron negatiflikleri, bu çalışmayla da bir kez daha teyit edilmiştir. Illgili literatür ile uyumlu bulunmuş olan sonuçlar, apokrin karsinom ile memenin diğer invaziv karsinomları arasında klinikopatolojik özellikler açısından zayıf bir anlamlı farkllık olduğunu göstermektedir.

Anahtar Kelimeler: Apokrin karsinom, Klinikopatolojik özellikler, Östrojen, progesteron, HER2 


\section{INTRODUCTION}

In the beginning of twentieth century, first definitions of apocrine carcinomas with mammarian origin, have been appeared in western medical literature. ${ }^{1}$ This type of tumor has also been named as apocrine gland carcinoma, or sweat gland carcinoma of the breast. ${ }^{2,3}$ Incidence of apocrine carcinoma has been reported to vary from 1 to $15 \%$ of all breast carcinomas, depending on variable criteria. ${ }^{3}$ Further studies have brought this wide range to a more significant rate as 0.4 to $4 \% .^{4-10}$

Currently, focal apocrine differentiation is accepted as a common feature in invasive carcinomas of no special type (NST). But when extensive apocrine differentiation is evident, carcinomas with apocrine differentiation (AC) are involved in rare and special types of invasive breast carcinomas (IBC) ${ }^{6,11} \mathrm{AC}$ is placed among special subtypes of breast carcinoma by the last classification of World Health Organization (WHO). ${ }^{12}$ Therefore the term of AC is strongly recommended to be reserved for those tumors in which all or nearly all of the neoplastic epithelium has apocrine cytological features. ${ }^{11}$ Clinicopathologic and prognostic features of $\mathrm{AC}$ were documented in various studies. ${ }^{13-21}$ Majority of related recent reports point on loss of estrogen (ER) and progesterone (PR) receptors, together with androgen (AR) and human epidermal growth factor receptor-2 (HER2) positivity. ${ }^{22-24}$ In several reports, AC was found to have similar clinical outcome with invasive ductal carcinoma of no special type (IDC (NST)). ${ }^{10,25}$

\section{MATERIALS AND METHODS}

2488 IBC patients, diagnosed in Hacettepe University between 2008 and 2013, were scanned retrospectively. Within those IBC cases, $20 \mathrm{AC}$ were found to form study group. In order to make a fair comparison, a control group consisting 40 IDC (NST) cases was formed by considering year of diagnosis and tumor grade similarity with study group. The clinicopathologic and prognostic features of AC group were documented and compared with low grade IDC (NST) group.

Extensive apocrine differentiation of neoplastic epithelium was accepted as necessarily diagnostic criteria for AC. Tumor cells with enlarged nuclei, prominent nucleoli, either abundant granular - eosinophilic or abundant foamy cytoplasm were recognized as apocrine cells. Invasive breast carcinomas with fo- cal apocrine differentiation were not included in AC. Modified Bloom - Richardson system was used for grading. ER, PR and HER2 evaluation was processed by immunohistochemical methods. For evaluation of ER and PR status, nuclear reaction in $1 \%$ or more of tumor cells was accepted as positive. HER 2 status was primarily evaluated by immunohistochemical methods: Those tumors that show strong circumferential staining in more than $30 \%$ of cells are accepted as HER2 positive. ASCO CAP guidelines were adhered in the evaluation of immunohistochemical tests. ${ }^{26,27}$ Tumors that show moderately strong circumferential membrane staining were directed to additional fluorescence in situ hybridization (FISH) procedures; in order to definitely determine HER2 status.

\section{Statistical Analysis}

Statistical analysis was made by using PASW statistics program version 18.0. Mean comparisons were processed by Mann Whitney test. Comparisons of other data between two groups were processed by chi-square test and Fisher's exact test. Results having p-values $<0.05$ were accepted as significant. "Relapse - free survival" was defined as the time between mastectomy operation and first recurrence.

\section{RESULTS}

In this study, AC accounted for $0.7 \%$ of IDC (The clinicopathologic features of AC group and of IDC (NST) group are summarized in Table 1.

Both ER and PR status were significantly different between AC and IDC groups. ER and PR negativity was concordant with AC.

Significance was controversial for tumor size; as $\mathrm{p}$ values were approximate to 0.05 . But, a significant difference of tumor size was obtained when data was taken as numeric values. This may be due to presence of several exceptional tumors with high diameters in the group of AC.

Comparison of nodal metastasis had a controversial result also. $\mathrm{P}$ value was slightly higher than 0.05 that was not significant but somewhat doubtful.

Mean age of AC patients at time of diagnosis was 53.9 , which was slightly above mean age of low grade IDC (NST). This difference was not significant. HER2 positivity of AC was $30 \%$. There was no significant difference between two groups with regard to HER2 status. ${ }^{28}$ 


\begin{tabular}{|c|c|c|c|}
\hline & $\begin{array}{l}\text { Apocrine Carcinoma } \\
n=20\end{array}$ & $\begin{array}{l}\text { Invasive Ductal } \\
\text { Carcinoma (NST) } \\
\mathrm{n}=40\end{array}$ & Significance \\
\hline Mean age at diagnosis & 53.9 & 52.7 & $\mathrm{NS}^{\mathrm{a}}$ \\
\hline Tumor size $(\mathrm{cm})$ & 5.1 & 2.6 & $p<0.05$ \\
\hline Tumor size 0-2 cm & $30 \%$ & $50 \%$ & \\
\hline $2.1-5 \mathrm{~cm}$ & $35 \%$ & $40 \%$ & $p=0.053$ \\
\hline$>5 \mathrm{~cm}$ & $35 \%$ & $10 \%$ & \\
\hline Nodal metastasis & $65 \%$ & $40 \%$ & $p=0.068$ \\
\hline Lymphatic - vascular invasion & $30 \%$ & $25 \%$ & $\mathrm{NS}^{\mathrm{a}}$ \\
\hline Estrogen receptor positivity & $30 \%$ & $85 \%$ & $p<0.05$ \\
\hline Progesterone receptor positivity & $35 \%$ & $75 \%$ & $p<0.05$ \\
\hline HER2 positivity & $30 \%$ & $27.5 \%$ & $N S^{a}$ \\
\hline
\end{tabular}

Chemotherapy procedures of the patients were heterogenic for both of the groups. Adjuvant therapy was applied to most of patients, while $2 \mathrm{AC}$ patients received neoadjuvant therapy. One of these 2 patients received docetaxel, trastuzumab, doxorubicin and cyclophosphamide as neoadjuvant and additionally trastuzumab as adjuvant therapy. The other one received cyclophosphamide, doxorubicin and 5-fluorouracil (CAF protocol) as neoadjuvant and additionally docetaxel as adjuvant therapy. One metastatic case of AC received cyclophosphamide, doxorubicin and zoledronic acid as adjuvant therapy. There were no patients who received neoadjuvant therapy in IDC (NST) group. One metastatic IDC case received doxorubicin, cyclophosphamide (AC protocol), docetaxel and trastuzumab as adjuvant therapy. AC protocol was commonly used in AC and IDC group, with some individual drug additions as docetaxel or trastuzumab. Docetaxel, adriablastin and cyclophosphamide (TAC protocol) was also commonly used, especially in AC group. Cyclophosphamide, methotrexate and 5-fluorouracil (CMF protocol) was also common in AC group. There were other patients with different chemotherapy plans as CAF protocol only, TC protocol (docetaxel plus cyclophosphamide), CEF protocol (cyclophosphamide, epirubicine and 5-fluorouracil) with or without addition of the formerly pronounced drugs. Only one AC patient did not receive any chemotherapy; but this situation was much more prominent for IDC group, in which a total of 15 patients did not receive any chemotherapy.

Tamoxifen and anastrozole were most widely used drugs as hormone therapy in both of the groups. Letrozol and goserelin were used in several cases. $11 \mathrm{AC}$ cases and 5 IDC cases received no hormone therapy at all.

14 of $20 \mathrm{AC}$ patients and 26 of 40 IDC patients received radiotherapy.

Mean follow up period was 29.1 months for AC group and 37.2 months for IDC (NST) group. There was neither relapse nor exitus in AC group, so overall and relapse-free survival rates were estimated to be excellent, at least for a 2.5-year period. There were two relapses in IDC group. One of those cases was censored as exitus. Since follow up periods felt short in duration, significant statistical comparisons for 5-year and 10-year survival rates between AC and IDC groups could not be performed; but groups were estimated to have no significant difference.

\section{DISCUSSION}

Besides current well-known morphologic diagnostic criteria, AC can also be differentiated from other IDC on molecular basis. ${ }^{29}$ Owing to its differential morphologic and genetic features; AC deserves to be approved as a special type. ${ }^{12}$

As far as we know, there were approximately 500 well documented cases of AC in medical literature. In our study, additional 20 cases of AC are presented as the widest group of Turkish patients. 
Our AC cases account for $0.7 \%$ of IBC, as a ratio consistent with worldwide average. ${ }^{4-10}$ Proximity of this ratio to the worldwide lower limit may depend on interpretation of diagnostic criteria. WHO defines AC as any invasive carcinoma in which the cells show the cytological features of apocrine cells. Necessity of extensive apocrine differentiation for a diagnosis of $\mathrm{AC}$, is also emphasized. ${ }^{12}$ In our opinion, "extensive apocrine differentiation" may be concretely defined as a specific minimal ratio to the total of tumor. Our suggestion is to fix this ratio as "at least $90 \%$ of tumor".

Since AC was already known to have similar clinical outcome with low grade IDC (NST), we matched groups for grade, in order to focus on independent parameters other than grade. ${ }^{13,16}$

Mean age of AC patients at diagnosis is $\mathbf{5 3 . 9}$ for our study. This is below the worldwide mean age, which is 57.1. When we compare AC with IDC (NST), there is no significant difference between mean ages. As the mean age of $\mathrm{AC}$ patients rises in other reports, a significant difference appears between AC and other IDC. ${ }^{10}$

When decimal numeric values are considered, AC is found to have larger mean tumor size than IDC (NST) of similar grade. This may be accepted as an exceptional result, because $5.1 \mathrm{~cm}$ is highly above the worldwide mean tumor size of AC, which is $2.4 \mathrm{~cm} .{ }^{10}$ When we categorize tumor size in to 3 groups and then make a comparison, again we find a difference between AC and IDC (NST), but significance is uncertain.

Our AC cases have high ratios of nodal metastasis. AC seems to have no difference from IDC (NST) with similar grade, in terms of nodal metastasis. When interpreted together with high tumor size, high ratio of nodal metastasis in our AC cases may unfortunately indicate delayed admission to hospital or inadequate public health education in Turkey. Relative unfavorable clinical outcome of Turkish AC patients is also documented by Kaya H, et al. ${ }^{30}$

Despite large tumor size and high ratio of nodal metastasis, lymphatic - vascular invasion seems to be in average limits. As there is no difference between AC and IDC, also there is no difference between Turkish and the other populations, by means of detecting lymphatic - vascular invasion.

ER and PR negativity of AC is a generally accepted feature. Our AC cases have similar but slightly differ- ent immunohistochemical results. $70 \%$ of our cases are ER negative and $65 \%$ of our cases are PR negative. These ratios are 10 to $15 \%$ below general average. ${ }^{10}$ But there are comprehensive studies with lower ratios of ER and PR negativity, such as 60\% and \%50 respectively. ${ }^{16}$ All those studies show that negativity of ER and PR receptors are valuable differential findings of $\mathrm{AC}$ as a special type of IDC, but these are not enough to label $\mathrm{AC}$ as an "estrogen and progesterone negative type".

$\mathrm{AC}$ is well known to have a higher ratio of HER2 positivity than the other IDC. ${ }^{28}$ In our study, ratio of HER2 positivity of AC is found to be $30 \%$, which is not significantly different from HER2 status of IDC (NST). As our AC and IDC (NST) groups are matched by grade, this result may be expectable. A significant difference will obviously be expected, if the two groups are not matched by grade. Since there are variable methods and different interpretations of results, it is hard to compare HER2 status of AC between different studies. Existence of wide range ratios as 15 to $85 \%$ in related studies may be explained by these reasons. ${ }^{10,30}$ As we mention in methods, standardization of HER2 evaluation may help investigators in making more reliable comparisons.

As prognostic criteria such as "relapse - free survival" and "overall survival" are mentioned, absence of significant difference between AC and IDC is documented by various investigators. ${ }^{4,9,10}$ Since our follow - up period is not long enough, we cannot comment on 5-year and 10-year survival rates.

In conclusion, clinicopathologic features of $\mathrm{AC}$ are generally same to IDC's; except some immunohistochemical expression status: ER and PR tend to be expressed significantly lower than IDC (NST). Despite lower expression of these hormone receptors, AC seems to have similar prognosis with IDC (NST). Longer follow-up periods are needed to extract more precise results about prognosis. Additionally, sparse number of recurrent and exitus cases make prognostic criteria more difficult to analyze. Subjectively, absence of any recurrence in AC group together with presence of 2 recurrences in IDC group may be an indistinct sign of better prognosis in AC patients. As original articles from different countries of the world accumulate, this rare special type of IDC may be evaluated with a more efficient manner. 


\section{REFERENCES}

1. Krompecher E. Zur histogenese und morphologie der cystenmamma (maladie kystique reclus, cystadenoma schimmelbusch, mastitis chronica cystica könig) des intrakanalikularen kystadenoms und der kystadenokarzinome der brustdrüse (hidrokystoma, kystadenoma, hidrokystadenokarzinoma mammae). Beitr Pathol Anat 62: 403-410, 1916.

2. Higginson JF, McDonald JR. Apocrine tissue, chronic cystic mastitis and sweat gland carcinoma of the breast. Surg Gynecol Obstet 88: 1-10, 1949.

3. Wald M, Kakulas BA. Apocrine gland carcinoma (sweat gland carcinoma) of the breast. Aust N Z J Surg 33: 200-204, 1964.

4. Frable WJ, Kay S. Carcinoma of the breast: histologic and clinical features of apocrine tumors. Cancer 21: 756-763, 1968.

5. Mossler JA, Barton TK, Brinkhous AD, et al. Apocrine differentiation in human mammary carcinoma. Cancer 46: 24632471,1980 .

6. Eusebi V, Millis RR, Cattani MG, et al. Apocrine carcinoma of the breast. A morphologic and immunocytochemical study. Am J Pathol 123: 532-541, 1986.

7. Gadaleanu V, Galatar N. Apocrine carcinoma of the breast. Morphol Embryol 32: 33-38, 1986.

8. Aoyagi $\mathrm{H}$, Ishida $\mathrm{T}$, Yamada I, et al. Ten cases of an apocrine carcinomas of the breast and a review of cases in the Japanese literature. Gan no rinsho 36: 681-690, 1990

9. Takeuchi H, Tsuji K, Ueno H, et al. Clinicopathological feature and long-term prognosis of apocrine carcinoma of the breast in Japanese women. Breast Cancer Res Treat 88: 49-54, 2004.

10. Tanaka K, Imoto S, Wada N, et al. Invasive Apocrine Carcinoma of the Breast: Clinicopathologic Features of 57 Patients. Breast J 14(2): 164-168, 2008.

11. Rosen PP, ed. Rosen's Breast Pathology, 2nd edition, Lippincott Williams \& Wilkins, Philedelphia, 2001: 483-495.

12. Lakhani SR, Ellis IO, Schnitt SJ, et al. WHO Classification of Tumours of the Breast. 4th edition. Lyon, 2012: 53.

13. d'Amore ES, Terrier-Lacombe MJ, Travagli JP, et al. Invasive apocrine carcinoma of the breast: a long term follow-up study of 34 cases. Breast Cancer Res Treat 12: 37-44, 1988.

14. Sapp M, Malik A, Hanna W. Hormone receptor profile of apocrine lesions of the breast. Breast J 9: 335-336, 2003.

15. Japaze H, Emina J, Diaz C, et al. 'Pure' invasive apocrine carcinoma of the breast: a new clinicopathological entity? Breast 14: 3-10, 2005.

16. Abati AD, Kimmel M, Rosen PP. Apocrine mammary carcinoma. A clinicopathologic study of 72 cases. Am J Clin Pathol 94: 371-377, 1990.

17. Matsuo K, Fukutomi T, Hasegawa T, et al. Histological and immunohistochemical analysis of apocrine breast carcinoma. Breast Cancer 9: 43-49, 2002.

18. Matsuo K, Fukutomi T, Tsuda H, et al. Apocrine carcinoma of the breast: clinicopathological analysis and histological subclassification of 12 cases. Breast Cancer 5: 279-284, 1998.

19. Honma N, Takubo K, Akiyama $F$, et al. Expression of GCDFP-15 and AR decreases in larger or node-positive apocrine carcinomas of the breast. Histopathology 47: 195-201, 2005.

20. Tavassoli FA, Norris HJ. Intraductal Aporcine Carcinoma: a clinicopathologic study of 37 cases. Mod Pathol 7: 813-818, 1994.
21. Leal C, Henrique R, Monteiro P, et al. Apocrine ductal carcinoma in situ of the breast: histologic classification and expression of biologic markers. Hum Pathol 32: 487-493, 2001.

22. Bhargava R, Dabbs DJ. Use of immunohistochemistry in diagnosis of breast epithelial lesions. Adv Anat Pathol 14: 93-107, 2010.

23. Niemeier LA, Dabbs DJ, Beriwal S, et al. Androgen receptor in breast cancer: Expression in estrogen receptor-positive tumors and in estrogen receptor-negative tumors with apocrine differentiation. Mod Pathol, 23: 205-212, 2010.

24. Suzuki T, Miki Y, Takagi K, et al. Androgens in human breast carcinoma. Med Mol Morphol 43: 75-81, 2010.

25. Özen Ö, Sar A, Demirhan B. Memenin apokrin karsinomunun ayirici tanisinda morfolojik histokimyasal ve immünhistokimyasal bulgular. J Breast Health 3: 69-74, 2007.

26. Hammond ME, Hayes DF, Dowsett M, et al. American Society of Clinical Oncology/College of American Pathologists guideline recommendations for immunohistochemical testing of estrogen and progesterone receptors in breast cancer. Arch Pathol Lab Med, 134: 907-922, 2010.

27. Wolff AC, Hammond ME, Schwartz JN, et al. American Society of Clinical Oncology/College of American Pathologists guideline recommendations for human epidermal growth factor receptor 2 testing in breast cancer. J Clin Oncol 25: 118145, 2007.

28. Bhargava R1, Beriwal S, Striebel JM, Dabbs DJ. Breast cancer molecular class ERBB2: preponderance of tumors with apocrine differentiation and expression of basal phenotype markers CK5, CK5/6, and EGFR. Appl Immunohistochem Mol Morphol 18: 113-118, 2010.

29. Celis JE, Cabezón T, Moreira JM, et al. Molecular characterization of apocrine carcinoma of the breast: validation of an apocrine protein signature in a well-defined cohort. Mol Oncol 3: 220-237, 2009.

30. Kaya H, Bozkurt SU, Erbarut I, Djamgoz BA. Apocrine carcinomas of the breast in Turkish women: Hormone receptors, c-erbB-2 and p53 immunoexpression. Pathol Res Pract 204: 367-371, 2008.

\section{Correspondence}

Dr. Halil KIYICI

Mevlana Üniversitesi Tıp Fakültesi

Tıbbi Patoloji Anabilim Dalı

Selçuklu, KONYA / TURKEY

Tel: (+90.533) 2247208

e-mail: halilkiyici@hotmail.com 